\title{
Retinal Ganglion Cell Topography and Spatial Resolving Power in Penguins
}

\author{
João Paulo Coimbra ${ }^{\mathrm{a}-\mathrm{c}}$ Paul M. Nolan ${ }^{\mathrm{d}}$ Shaun P. Collin ${ }^{\mathrm{a}-\mathrm{c}}$ Nathan S. Hart ${ }^{\mathrm{a}-\mathrm{c}}$ \\ aSchool of Animal Biology, ${ }^{\text {b}}$ The Oceans Institute, The University of Western Australia, Crawley, W.A., and

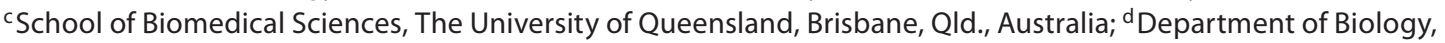 \\ The Citadel, Charleston, S.C., USA
}

\section{Key Words}

Retinal topography $\cdot$ Penguins $\cdot$ Aptenodytes patagonicus •

Eudyptula minor $\cdot$ Spatial resolving power $\cdot$ Stereology •

Retinal ganglion cell • Area gigantocellularis ·

Evolutionary history

\section{Abstract}

Penguins are a group of flightless seabirds that exhibit numerous morphological, behavioral and ecological adaptations to their amphibious lifestyle, but little is known about the topographic organization of neurons in their retinas. In this study, we used retinal wholemounts and stereological methods to estimate the total number and topographic distribution of retinal ganglion cells in addition to an anatomical estimate of spatial resolving power in two species of penguins: the little penguin, Eudyptula minor, and the king penguin, Aptenodytes patagonicus. The total number of ganglion cells per retina was approximately 1,200,000 in the little penguin and 1,110,000 in the king penguin. The topographic distribution of retinal ganglion cells in both species revealed the presence of a prominent horizontal visual streak with steeper gradients in the little penguin. The little penguin retinas showed ganglion cell density peaks of 21,867 cells $/ \mathrm{mm}^{2}$, affording spatial resolution in water of $17.07-17.46$ cycles/de- gree (12.81-13.09 cycles/degree in air). In contrast, the king penguin showed a relatively lower peak density of ganglion cells of 14,222 cells $/ \mathrm{mm}^{2}$, but - due to its larger eye - slightly higher spatial resolution in water of 20.40 cycles/degree (15.30 cycles/degree in air). In addition, we mapped the distribution of giant ganglion cells in both penguin species using Nissl-stained wholemounts. In both species, topographic mapping of this cell type revealed the presence of an area gigantocellularis with a concentric organization of isodensity contours showing a peak in the far temporal retina of approximately 70 cells $/ \mathrm{mm}^{2}$ in the little penguin and 39 cells $/ \mathrm{mm}^{2}$ in the king penguin. Giant ganglion cell densities gradually fall towards the outermost isodensity contours revealing the presence of a vertically organized streak. In the little penguin, we confirmed our cytological characterization of giant ganglion cells using immunohistochemistry for microtubule-associated protein 2 . This suite of retinal specializations, which is also observed in the closely related procellariiform seabirds, affords the eyes of the little and king penguins panoramic surveillance of the horizon and motion detection in the frontal visual field.

Copyright $\odot 2012$ S. Karger AG, Basel

\section{KARGER}

Fax +4161306 1234

E-Mail karger@karger.ch

www.karger.com (c) 2012 S. Karger AG, Basel

0006-8977/12/0804-0254\$38.00/0

Accessible online at:

www.karger.com/bbe
João Paulo Coimbra

Neuroecology Group (M317), School of Animal Biology and The Oceans Institute

The University of Western Australia

35 Stirling Highway, Crawley, WA 6009 (Australia)

Tel. +61 86488 3960, E-Mail joaopco@ terra.com.br 


\section{Introduction}

Penguins (Sphenisciformes) are a group of oceanic flightless birds that exhibit unique morphological, physiological and behavioral adaptations for their amphibious lifestyle [Martínez, 1992]. They possess waterproof and insulating feathers, wings and streamlined body morphology, which improve locomotion underwater, allowing them to successfully occupy a marine niche when not on land [Martínez, 1992; Ksepka and Ando, 2011]. To cope with the different physical constraints on vision that are inherent in aquatic and terrestrial environments, penguins possess specialized optics, including a relatively flat cornea and nearly spherical lens, to compensate for the loss of corneal refractive power upon immersion [Sivak, 1976]. Penguins have an emmetropic eye in air and show slight hyperopia in water [Sivak, 1976; Sivak and Millodot, 1977], which is thought to be mitigated by accommodative mechanisms [Howland and Sivak, 1984; Sivak et al., 1987]. Penguins also possess long and narrow binocular visual fields, characteristic of birds that use visual guidance of bill position while foraging [Martin and Young, 1984; Martin, 1999], and cone visual pigments that are tuned towards the blue-green parts of the spectrum, which may be related to the spectral properties of their aquatic environment [Bowmaker and Martin, 1985].

Although some information is available on the optical architecture, visual field topography and spectral sensitivity of the penguin eye, very little is known about the topographic distribution of neurons in the penguin retina and its ecological and evolutionary significance. Light and electron microscopic analyses of photoreceptor types in the Magellanic penguin, Spheniscus magellanicus, reveal the same basic photoreceptor complement as observed in other birds, with the presence of single cones, double cones and rods; however, their outer segment diameters are larger in comparison to terrestrial birds, possibly reflecting an adaptation for increasing sensitivity during diving in dim environments [Suburo and Scolaro, 1999]. The topographic distribution of retinal ganglion cells in S. magellanicus exhibits a band of high ganglion cell density indicative of a horizontal visual streak with a peak in the central retina [Suburo et al., 1991]. Horizontal visual streaks are characterized by a band of elevated retinal ganglion cell density across the nasotemporal axis and have been documented for several other vertebrates, including birds [Hughes, 1977; Bravo and Pettigrew, 1981; Wathey and Pettigrew, 1989; Hayes and Brooke, 1990; Boire et al., 2001]. Horizontal visual streaks are common in species that live in open and featureless habitats, such as grasslands and open oceans/beaches, and are thought to increase fine detail discrimination across the horizon, ultimately aiding the detection of predators, prey and conspecifics without the need for significant eye and/or head movements [Hughes, 1977; Collin, 1999].

The area gigantocellularis is another type of retinal specialization, first described in some procellariiform seabirds using silver staining methods [Hayes et al., 1991] and later identified in Nissl-stained retinal wholemounts in four species of tyrant flycatcher passerine birds [Coimbra et al., 2006, 2009]. This retinal specialization is formed by a cohort of giant retinal ganglion cells which are more abundant in the periphery of the temporal retina [Hayes et al., 1991; Coimbra et al., 2006, 2009]. As these giant ganglion cells occur in very low densities, it is unlikely that they play a role in spatial resolution, but rather in motion detection in the frontal visual field. This is based on their temporal location within the retina and their morphological similarity to a subpopulation of large ganglion cells characterized electrophysiologically as brisk transient, fast-conducting alpha ganglion cells in mammals [Peichl et al., 1987; Hayes et al., 1991; Peichl, 1991]. Using Nissl-stained retinas, Suburo et al. [1991] mapped the distribution of very large ganglion cells in the Magellanic penguin and showed that these cells were more concentrated in the temporal periphery in Nissl-stained retinas. Although not termed an area gigantocellularis by these authors, this specialization may be comparable and could play an important role in the identification and capture of fast-moving fishes and cephalopods during prey pursuit. It is currently unknown whether other avian species share this retinal trait.

Comparative studies on retinal topography undertaken within a phylogenetic framework allow a better understanding of the evolutionary history of retinal specializations. A combination of morphological and molecular data support the placement of penguins within a large seabird clade that includes albatrosses and petrels (Procellariiformes), divers (Gaviiformes), pelicans (Pelecaniformes) and storks (Ciconiiformes) [Livezey and Zusi, 2007; Hackett et al., 2008; Ksepka and Ando, 2011]. Within this large group, penguins are thought to be more closely related to albatrosses and petrels, sharing a common ancestor that existed approximately 71 million years ago [Baker et al., 2006]. Amongst penguins (Sphenisciformes), it has been proposed that the largest-bodied genus, Aptenodytes (king and emperor penguins), was the first to branch off from the last common ancestor of penguins around 40 million years ago [Baker et al., 2006] and therefore would show more plesiomorphic characteris- 
tics. In contrast, the smallest-bodied genus, Eudyptula (little penguins), which underwent much more recent speciation events, branched off about 2.7 million years ago and would be expected to possess more apomorphic traits. Hence, the phylogenetic position of these two penguin species offers an excellent opportunity to identify plesiomorphic and/or apomorphic retinal traits in this group of marine birds.

King penguins (Aptenodytes patagonicus; Miller, 1778) and little penguins (Eudyptula minor; Forster, 1781) not only differ in their size and evolutionary history but also in their habitat, behavioral ecology and foraging tactics [Klomp and Wooller, 1988; Kooyman et al., 1992; Martínez, 1992; Cannell and Cullen, 1998; Ropert-Coudert et al., 2006]. As in other penguin species, little and king penguins rely heavily on the ocean to obtain food resources but regularly use terrestrial environments to breed and nest [Martínez, 1992]. King penguins are offshore feeders that spend much of their time in pelagic waters, coming inshore to breed on flat open beaches [Martínez, 1992]. In contrast, little penguins are inshore feeders and nest in holes dug in sand at the base of cliffs or in sand dunes [Martínez, 1992]. Consequently, during their time on land, little penguins experience a much more obstructed view of the horizon than king penguins due to the proximity of vegetation and the enclosed nature of their excavated holes. Another interesting difference between these two species is the depth in the water column to which they dive. King penguins forage at much deeper depths (100-300 m) and are therefore exposed to less light than little penguins, which predominantly dive and forage at much shallower depths $(10-50 \mathrm{~m})$, where light is far more abundant [Gales et al., 1990; Kooyman et al., 1992]. This variation in diving stratification is reflected in each species' diet and foraging techniques, with king penguins targeting mainly midwater lanternfishes (Myctophidae), which they approach from below, in contrast to little penguins, which feed on a range of shoaling fishes (but occasionally squid), which they approach from above [Kloomp and Wooller, 1988; Kooyman et al., 1992; Ropert-Coudert et al., 2006].

Given the ecological diversity and phylogenetic history of little and king penguins, we were motivated to assess whether the location and type of any retinal specializations in these amphibious seabirds were reflected in differences in each species' behavioral ecology and habitat and/or represented common traits shared with their close relatives, the procellariiform seabirds. Therefore, we used the retinal wholemount technique and stereological methods to quantify the total number and topo- graphic distribution of ganglion cells and estimate the spatial resolving power in the little penguin and the king penguin. As both little and king penguins predominantly inhabit open environments, we predicted that both species will possess a horizontal visual streak; however, we expect that this retinal trait will be more prominent in king penguins because little penguins occupy a structurally more complex microhabitat when on land. Moreover, because king penguins dive deeper than little penguins and therefore forage under reduced levels of illumination, we predict that estimates of spatial resolving power will be lower in A. patagonicus. We also predict the presence of an area gigantocellularis in the temporal retina of both species to aid in the capture of moving prey during pursuit dives.

\section{Methods}

\section{Specimens}

Eyes were obtained from one adult king penguin, A. patagon$i c u s$, and two adult little penguins, E. minor. A single king penguin eye was collected postmortem at Ile de la Possession, Crozet Archipelago, Southern Indian Ocean. Little penguin eyes were collected from individuals that had to be euthanized at the Veterinary Hospital at Perth Zoo, Western Australia. All procedures in this investigation were approved by the University of Queensland and University of Western Australia Ethics Committees (AEC No. RA/3/100/927).

\section{Tissue Processing and Preparation of Nissl-Stained Retinal} Wholemounts

Eyes from both species were enucleated in the field or at the veterinary hospital, and the axial length was measured using a digital calliper. The cornea and lens were removed and the eyecup was fixed in $4 \%$ paraformaldehyde in $0.1 \mathrm{M}$ phosphate buffer (PB; $\mathrm{pH}=7.2-7.4$ ) for approximately $2 \mathrm{~h}$. After this period, fixation was stopped by transferring the eyecups to phosphate-buffered saline (PBS; $\mathrm{pH}=7.2-7.4)$. Eyecups were then stored in PBS containing $0.1 \%$ sodium azide and shipped/transported to the laboratory. Retinal wholemounts were dissected and processed following standard methods [Stone, 1981; Coimbra et al., 2006]. Retinal orientation was given by the position of the pecten, which is located in the ventral retina [Wood, 1917]. Remnants of retinal pigmented epithelium still attached to the retinal wholemounts were bleached in a $0.9 \%$ saline solution containing $12 \%$ hydrogen peroxide and 1 drop of $28 \%$ ammonia for $1 \mathrm{~h}$ at room temperature [Petry et al., 1993; Hemmi and Grünert, 1999]. After bleaching, retinas were rinsed overnight in PBS and flattened onto a gelatinized slide with the ganglion cell layer uppermost. To improve fixation of the retinal wholemount, ensure adhesion onto the slide and augment differentiation of cells during staining, the retinal preparation was incubated in formaldehyde vapors at room temperature overnight [Stone, 1981]. Retinal wholemounts were then rehydrated, stained for $25 \mathrm{~min}$ with an aqueous solution of $0.1 \%$ cresyl violet (Sigma), dehydrated in an ethanol series, cleared in 
xylene and finally mounted with Entellan New (Merck) [Coimbra et al., 2006]. As retinal wholemounts were attached to the slide during all staining steps, shrinkage was negligible and confined to the borders of the ora serrata and edges of radial cuts [Wässle et al., 1981; Peichl, 1992].

\section{Labeling of Giant Ganglion Cells Using}

Immunohistochemistry

We used microtubule-associated protein 2 (MAP2) antibody to selectively label giant ganglion cells in the little penguin retina. Antibodies against MAP2 are reported to label a subpopulation of large ganglion cells in a range of vertebrates [Tucker and Matus, 1987; Gábriel et al., 1992] but have not been used previously in avian retinal wholemounts to characterize the topographic distribution of this cell type. Immunohistochemistry in avian retinal wholemounts may result in uneven and inhomogeneous labeling because penetration of antibodies is greatly hindered by the considerable thickness of the nerve fiber layer in the central retina and in the vicinity of the pecten. Enzymatic treatment with collagenase has been reported to facilitate antibody penetration by breaking the collagen fibers in the inner limiting membrane in primate retinas [Watanabe and Rodieck, 1989; Yamada et al., 2001; Gomes et al., 2005]. Collagenase treatment of the entire avian retinal wholemount improves antibody penetration at central eccentricities at the expense of digestion of cellular elements at the periphery as the thickness of the nerve fiber layer is considerably thinner in this region [unpubl. observations]. Therefore, to circumvent these problems and obtain consistent immunolabeling, we incubated retinal wholemount pieces in a solution of low collagenase concentration for different durations according to the fiber layer thickness. We also used a series of permeabilization treatments with methanol and high-concentration Triton X-100 to ensure even and homogeneous antibody penetration at all locations in the little penguin retinal wholemounts. In brief, after dissection, the retina was mounted onto a hardened filter paper (Whatman, No. 50) and then carefully cut into 4 peripheral pieces and a single central piece using a scalpel blade. Prior to sectioning, a drawing was made to record important features of the wholemount (location of radial cuts, discrete peripheral tears) to aid reconstruction of the wholemount after the immunohistochemical procedures. Peripheral retinal wholemount pieces were incubated in $0.01 \%$ collagenase (Type II, Sigma) in $0.1 \mathrm{M} \mathrm{PB}$ for $2 \mathrm{~min}$, while the single central piece (with a thicker fiber layer) was incubated in a solution with the same concentration of collagenase as above but for a period of $12-15 \mathrm{~min}$. The retinal pieces were then thoroughly rinsed in $0.1 \mathrm{M} \mathrm{PB} 3$ times for 5 min each.

Following the collagenase treatment, retinal pieces were incubated in a solution containing $10 \%$ methanol and $3 \% \mathrm{H}_{2} \mathrm{O}_{2}$ in $0.1 \mathrm{M} \mathrm{PB}(\mathrm{pH}=7.2-7.4)$ for $15 \mathrm{~min}$. The retinal wholemount pieces were incubated in 5\% Triton X-100 (Sigma) for 5 min (twice) and a further $20 \mathrm{~min}$ and then rinsed 3 times in $0.1 \mathrm{M} \mathrm{PB}$ for $5 \mathrm{~min}$ per rinse. Thereafter, the retinal pieces were incubated in a mixture containing the MAP2 primary antibody (1:500; MAB 3418, Millipore), $5 \%$ normal donkey serum (Millipore) and $0.3 \%$ Triton $\mathrm{X}-100$ in $0.1 \mathrm{M} \mathrm{PB}(\mathrm{pH}=7.2-7.4)$ for $24 \mathrm{~h}$ with gentle rocking. Retinal pieces were then rinsed 3 times with $0.1 \mathrm{M} \mathrm{PB}$ for 5 min each and incubated in biotinylated donkey antimouse secondary antibody (1:200; Jackson ImmunoResearch) for $2 \mathrm{~h}$. Retinal pieces were then transferred to a solution containing avidinbiotin complex (Vectastain ABC kit, Vector Laboratories) and further incubated for $1 \mathrm{~h}$. Finally, the retinal pieces were rinsed 3 times in $0.1 \mathrm{M} \mathrm{PB}$ for 5 min each before reacting them in a nickelenhanced peroxidase solution containing diaminobenzidine tetrahydrochloride as the chromogen (Peroxidase Substrate kit, Vector Laboratories). After the reaction, the retinal wholemount pieces were rinsed overnight in $0.1 \mathrm{M} \mathrm{PB}$ and mounted vitreal side up onto a nongelatinized slide. Retinal pieces were then carefully reassembled using anatomical features recorded previously to reconstruct the retinal wholemount. The preparation was left to semi-dry at room temperature and then coverslipped in aqueous mounting medium (Vectamount AQ, Vector Laboratories). Shrinkage in retinal preparations mounted in aqueous medium is negligible [Peichl et al., 2004]. The MAP2 immunostaining pattern obtained in this study is consistent with previous reports that evaluated the specificity of this antibody in avian retinas [Tucker and Matus, 1987]. Secondary antibody specificity was assessed by incubating the retinal pieces in a mixture in which the primary antibody had been omitted [Saper and Sawchenko, 2003]. No labeling was detected.

\section{Stereological Assessment of Total Number and Topographic}

Distribution of Retinal Ganglion Cells

Using the optical fractionator method [West et al., 1991] with modifications for the use in retinal wholemounts [Coimbra et al., 2009], we estimated the total number and topographic distribution of retinal ganglion cells in the ganglion cell layer of both little and king penguins. Briefly, the retina was considered as a single section, and therefore the section sampling fraction was 1 . The penguin ganglion cell layer predominantly comprises a single layer of neurons except within the central part of the visual streak, where 2 or 3 sublaminae were observed. As all neurons were easily identified by focusing through the ganglion cell layer, both in the periphery and within the streak, the optical disector height was the same as the thickness of the ganglion cell layer at all eccentricities, giving a thickness sampling factor of 1 . Therefore, only the area sampling fraction, which is the ratio between the counting frame and the sampling grid, was used to estimate the total number of retinal ganglion cells, according to the following algorithm:

$$
\mathrm{N} \text { total }=\Sigma \mathrm{Q} \times 1 / \mathrm{asf}
$$

where $\Sigma \mathrm{Q}$ is the sum of total neurons counted and asf is the area sampling fraction [West et al., 1991].

The optical fractionator is a state-of-the-art stereological method to estimate the total number of neurons and has been widely used in a range of brain areas in a variety of species [Amrein and Slomianka, 2010; Gatome et al., 2010a, b; Bhagwandin et al., 2011; Kern et al., 2011]. However, this method has only recently been used to measure the total number and topographic distribution of neurons in retinal wholemounts of tyrant flycatchers [Coimbra et al., 2009] and hydrophiid sea snakes [Hart et al., 2012]. The use of this method in retinal wholemounts has several advantages. Firstly, the use of stereological softwares allows time-efficient and accurate quantification of cell numbers, enabling the performance of pilot experiments with different sampling designs to determine the optimal counting frame and sampling grid size. Secondly, as the sampling grid is placed in a uniform, random and systematic fashion across the retinal area, all locations have equal sampling probability, avoiding oversampling in specific areas. If applicable, high-frequency sampling 

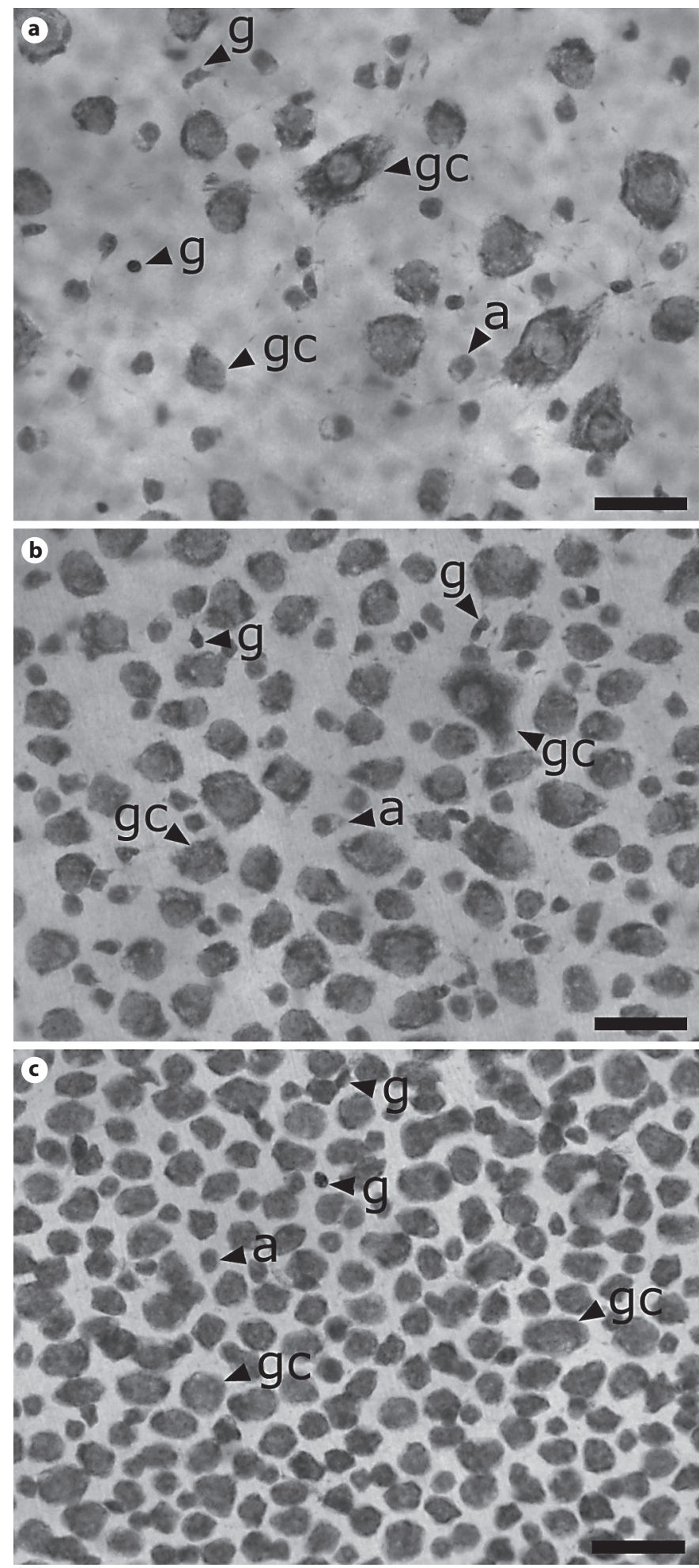

Fig. 1. Photomicrographs of the retinal ganglion cell layer of the little penguin (E. minor) depicting the cytological criteria used to distinguish ganglion cells from amacrine and glial cells at regions of low (a), moderate (b) and high density (c). Note that the same can also be obtained in regions of high cell density (i.e. streaks, areas or foveas). Thirdly, estimates of the total number of retinal neurons using this method are not affected by the distribution of the particles counted [West et al., 1991; Schmitz and Hof, 2005]; usually estimates of the total number of neurons in retinal wholemounts rely on the integration of isodensity lines and thereby add a subjective component that reflects how the contour lines were traced. The optical fractionator thus provides accurate and reproducible data when comparing the proportion of neuronal classes within a given retinal layer. The standardized use of this technique in retinal wholemounts minimizes sampling design variability among studies and facilitates comparisons across taxa.

The outlines of the Nissl-stained retinal wholemounts were digitized using a $\times 4$ /numerical aperture (NA) 0.13 objective on a microscope (Olympus BX50) equipped with a motorized stage (MAC200, Ludl Electronics Products, USA) and connected to a computer running Stereo Investigator software (Microbrightfield, USA). The ganglion cell layer was outlined close to the limits of the retinal borders (at the ora serrata) and along the radial cuts but excluding other retinal layers that can be seen on the transverse view after wholemounting. The outline of the base of the pecten was subtracted from the total ganglion cell layer area. In both the little and king penguin retinas, cell density in the ganglion cell layer appeared low at peripheral eccentricities, changing steeply to form a horizontal band of high cell density in the central part of the retina. At low-power magnification, this horizontal band could be easily delineated using the increase in cell density to establish its landmarks. This allowed us to use different stereological sampling schemes in high- and low-density regions to optimize the quantitative estimations of total number and topographic distribution of ganglion cells.

Cytological criteria proposed by Ehrlich [1981] to distinguish retinal ganglion cells from amacrine and glial cells in the avian ganglion cell layer were used. Cell profiles showing polygonal soma with dense accumulation of Nissl substance in the cytoplasm, an eccentric nucleus and a prominent nucleolus were classified as retinal ganglion cells. Smaller, rounder and more palely stained profiles, with no evident Nissl substance in the cytoplasm and with a characteristic teardrop-shaped cell body, were classified as amacrine cells. Darkly stained profiles displaying a small, round or slightly elongated cell body were recognized as glial cells. These cytological criteria were consistent at all eccentricities and were unambiguously applicable in low- and high-density regions in the retinas of both species of penguin (fig. 1). Because retinal ganglion cells were reliably identified at all eccentricities across the retinas of both species, we opted to exclude amacrine and glial cells from the counting procedures.

cytological profiles are clearly observed in the regions illustrated. The same cytological criteria were applicable in the ganglion cell layer of the king penguin, $A$. patagonicus. $\mathrm{gc}=$ Ganglion cell; $\mathrm{a}=$ amacrine cell; $\mathrm{g}=$ glial cell. Scale bars $=25 \mu \mathrm{m}$. 
Counting frame and sampling grid sizes used to estimate the total number and topographic distribution of ganglion cells in the horizontal band and periphery in the retinas of both little and king penguins are listed in table 1 . Sampling grids were placed in a random, uniform and systematic fashion covering the area of each contour. Using a $\times 60 / \mathrm{NA} 1.35$ oil immersion objective, only ganglion cells that lay entirely within the counting frame or intersected the acceptance lines without touching the rejection lines were counted at each sampling site [Gundersen, 1977; Sterio, 1984]. Approximately 200 sampling points were obtained both in the horizontal streak and the periphery (table 2). These stereological parameters were chosen on the basis of a pilot experiment to achieve a Schaeffer coefficient of error $(\mathrm{CE})<0.1$, which is deemed appropriate in the present study because variance introduced by the counting procedures contributes very little to the observed group variance [Glaser and Wilson, 1998; Slomianka and West, 2005]. The Schaeffer CE gauges the accuracy of a fractionator-based estimation of a population size with either a random or nonrandom distribution. The Schaeffer CE provides a more precise (less scattered) estimate, which is closer to the simulated true CE in comparison to other CE estimators [Glaser and Wilson, 1998].

In Nissl-stained retinal wholemounts, giant ganglion cells were identified by their large stellate cell body and dense accumulation of Nissl substance in their cytoplasm. These cells were readily recognized at the temporal retina in both penguin species. Recognition of this giant ganglion cell type was not possible in central eccentricities in Nissl-stained preparations due to the homogeneous appearance of cell morphologies as a result of elevated density packing. Therefore, to avoid bias in our quantification and to define a reproducible sampling area, we outlined a contour around the limits where Nissl-stained giant ganglion cells were unambiguously identified. In the MAP2-immunolabeled retinal wholemounts of little penguin, immunopositive giant ganglion cells were recognized at all eccentricities. Counting frame and sampling grid sizes used to estimate the number and topographic distribution of giant ganglion cells in the temporal retina of Nisslstained preparations of both king and little penguin as well as across the entire retinal area in MAP2-immunolabeled retinal wholemounts of little penguin are listed in table 1 . All counting procedures were performed using a $\times 20 /$ NA 0.50 air objective and resulted in approximately 100 sites per sampling area in the Nissl-stained retinas in both penguin species and 200 sites per MAP2-immunoreacted retinal wholemount in the little penguin (table 1). To verify the estimates of the peak densities of giant ganglion cells in both the Nissl-stained and MAP2-immunolabeled retinas, we recounted the giant ganglion cells in the vicinity of the two highest values in the first estimate using the same counting frame sizes but a smaller sampling grid $(650 \times 650 \mu \mathrm{m}$ in the little penguin; $950 \times 950 \mu \mathrm{m}$ in the king penguin). To provide an estimate of the giant ganglion cell soma size, we used the optical fractionator sampling scheme to measure cell bodies within counting frames at $1 / 3$ intervals across the temporal retina for Nissl-stained wholemounts and across the entire area of MAP2immunoreacted retinas; giant ganglion cell somas were also measured within 4-6 counting frames adjacent to the peak density for both Nissl-stained and MAP2-labeled retinas. For giant ganglion cells, we applied the same counting rules described above, and in all sampling schemes the Schaeffer CE was below 0.1 .
Table 1. Stereological parameters defined to estimate the total number and topographic distribution of ganglion cells in the ganglion cell layer of the little and king penguins using the optical fractionator method

\begin{tabular}{llll}
\hline Species & Counting & Grid & Area \\
& frame & $\mu \mathrm{m} \times \mu \mathrm{m}$ & $\begin{array}{l}\text { sampling } \\
\text { fraction }\end{array}$ \\
& $\mu \mathrm{m} \times \mu \mathrm{m}$ & & \\
\hline
\end{tabular}

\section{E. minor}

Total ganglion cells

(Nissl)

$\begin{array}{lccc}\text { Streak } & 75 \times 75 & 400 \times 400 & 0.0351 \\ \text { Periphery } & 150 \times 150 & 1,700 \times 1,700 & 0.0078\end{array}$

Periphery

$150 \times 150 \quad 1,700 \times 1,700$

0.0078

Giant ganglion cells

(Nissl)

Temporal retina $\quad 500 \times 500 \quad 1,200 \times 1,200 \quad 0.1736$

Giant ganglion cells

(MAP2)

Whole retina $\quad 500 \times 500 \quad 1,700 \times 1,700 \quad 0.0865$

A. patagonicus

Total ganglion cells

(Nissl)

$\begin{array}{lccc}\text { Streak } & 75 \times 75 & 350 \times 350 & 0.0459 \\ \text { Periphery } & 250 \times 250 & 2,500 \times 2,500 & 0.0100\end{array}$

Giant ganglion cells

(Nissl)

Temporal retina $\quad 800 \times 800 \quad 1,400 \times 1,400 \quad 0.3265$

Table 2. Quantitative data obtained from retinal wholemounts of little and king penguin eyes using the optical fractionator method

\begin{tabular}{lllll}
\hline Species & $\begin{array}{l}\text { Area } \\
\mathrm{mm}^{2}\end{array}$ & $\begin{array}{l}\text { Number } \\
\text { of sites } \\
\text { counted }\end{array}$ & $\begin{array}{l}\text { Estimated total } \\
\text { number of retinal } \\
\text { ganglion cells }\end{array}$ & $\begin{array}{l}\text { Schaeffer } \\
\mathrm{CE}\end{array}$ \\
\hline
\end{tabular}

E. minor (Emi)

Emi01 (left eye)

$\begin{array}{lllll}\text { Streak } & 27.88 & 175 & 255,258 & 0.033 \\ \begin{array}{l}\text { Periphery } \\ \text { Total }\end{array} & 585.51 & 205 & 947,149 & 0.061 \\ \begin{array}{l}\text { Mean } \\ \text { Mea (right eye) }\end{array} & 613.39 & 380 & 1,222,407 & \\ \begin{array}{l}\text { Streak } \\ \text { Striphery }\end{array} & 62.88 & 204 & 329,073 & 0.047 \\ \begin{array}{l}\text { Periph } \\ \text { Total }\end{array} & 683.60 & 236 & 943,167 & 0.037 \\ \text { Mean } & & 440 & 1,272,240 & 0.062 \\ & & & & 0.049\end{array}$

A. patagonicus (Apa)

Apa01 (right eye)

$\begin{array}{lllll}\text { Streak } & 30.24 & -256 & 162,004 & 0.028^{-} \\ \text {Periphery } & 1,253.05 & 210 & 948,400 & 0.053 \\ \text { Total } & 1,283.29 & 466 & 1,110,404 & \\ \text { Mean } & & & & 0.041\end{array}$


To map the topographic distribution of ganglion cells in the little and king penguin retinas, cell counts at each sampling site were converted to an equivalent cell density per square millimeter. We used Arcview 3.2 software (Esri, Redlands, Calif., USA) to construct topographic maps depicting the distribution of ganglion cells in the retinas of both species using the spline interpolation method [Coimbra et al., 2006].

Photomicrographs were obtained using a digital camera (Microfire, Optronics, Calif., USA) coupled to a Stereo Investigator system. Digital photomicrographs were processed using Adobe Photoshop CS2 (San Jose, Calif., USA) for scaling and minor adjustment of the levels of brightness and contrast.

\section{Anatomical Estimation of Spatial Resolving Power}

The spatial resolving power in water and air was estimated using anatomical methods for both little and king penguins. To calculate the spatial resolving power in water, we estimated the posterior nodal distance (PND) of the little and king penguin eyes by multiplying their axial lengths by 0.71 , which represents the ratio of PND to axial length obtained from the underwater PND and axial length measurements of the Humboldt penguin (Spheniscus humboldti) eye [Martin and Young, 1984].

To estimate the retinal magnification factor (RMF), which represents the distance in retinal surface that subtends 1 degree, we used the following equation [Pettigrew et al., 1988]:

$\mathrm{RMF}=2 \pi \mathrm{PND} / 360$.

Finally, we considered that retinal ganglion cells in the peak region are organized in an approximate hexagonal array and used their maximum density to estimate the highest spatial frequency as determined by the Nyquist limits of spatial resolution according to the following equation [Snyder and Miller, 1977; Williams and Coletta, 1987]:

$$
\mathrm{f}_{\mathrm{N}}=0.5 \times \mathrm{RMF} \times(2 \mathrm{D} / \sqrt{3})^{1 / 2}
$$

where $\mathrm{D}$ represents maximum density.

Anatomical estimates of spatial resolving power using the total peak density of retinal ganglion cells should be considered as upper limits of retinal resolution because it is not known whether all retinal ganglion cells in the peak region are involved in fine discrimination tasks [Wässle, 2004; Reuter and Peichl, 2008].

The penguin eye is emmetropic in air and water [Howland and Sivak, 1984; Sivak et al., 1987]. However, because the visual image is smaller in air than water, we multiplied the estimates of spatial resolving power in water by a factor of 0.75 (ratio of refractive index of air to aqueous or vitreous humor) to obtain an estimate of retinal resolution in air [Hanke et al., 2009] for both little and king penguins.

\section{Results}

\section{Stereological Assessment of the Total Number of \\ Retinal Ganglion Cells}

In the two little penguin retinal wholemounts, the total area of the ganglion cell layer was 613 and $683 \mathrm{~mm}^{2}$, respectively. In the single king penguin retina analyzed, the total ganglion cell layer area was approximately dou- ble that of the little penguin area at $1,283 \mathrm{~mm}^{2}$. The total number of retinal ganglion cells estimated by the optical fractionator method was relatively similar in both species, with estimates ranging from 1,110,000 ganglion cells in king penguins to around 1,200,000 ganglion cells in little penguins (table 2).

The number of retinal ganglion cells in the horizontal band of both species of penguins differed considerably. In the little penguin, the band consists of approximately 300,000 ganglion cells, compared to 160,000 in the king penguin. The total number of ganglion cells was found to be very similar in the midperiphery/periphery in the retinas of both species, i.e. around 950,000 ganglion cells. The Schaeffer CE was below 0.1 in all cases and, therefore, was deemed appropriate for the optical fractionator estimates of the total number of retinal ganglion cells in both penguin species (table 2).

\section{Distribution of Retinal Ganglion Cells in the Penguin Retina}

The topographic distribution of ganglion cells in Nissl-stained retinal wholemounts of the little penguin and king penguin illustrated the presence of a pronounced horizontal visual streak (fig. $2 \mathrm{a}, \mathrm{b}$ ). In both species, isodensity lines of 500 and 1,000 cells $/ \mathrm{mm}^{2}$ are organized in a concentric fashion until the midperipheral retina. From the midperipheral to central retinal regions, the isodensity lines become more elliptical and elongated in shape to form the horizontal visual streak in both species. The centroperipheral gradient in ganglion cell densities differs between the two penguin species. The little penguin shows a much steeper centroperipheral gradient of $36: 1$, in contrast to the king penguin, which has a much shallower centroperipheral gradient of 18:1. The horizontal streak runs across the nasotemporal meridian and is situated around $2 \mathrm{~mm}$ (little penguin) and $3 \mathrm{~mm}$ (king penguin) above the tip of the pecten. Within the innermost isodensity lines of the horizontal visual streak of both species, retinal ganglion cells show a peak density of 21,867 cells $/ \mathrm{mm}^{2}$ in the little penguin and 14,222 cells/ $\mathrm{mm}^{2}$ in the king penguin.

\section{Cytological Characterization and Distribution of \\ Giant Ganglion Cells}

In Nissl-stained retinal wholemounts, a cohort of giant retinal ganglion cells was observed in the temporal quadrant of the retinas in both little and king penguins. These cells stood out from the total retinal ganglion cell population in the temporal region due to their staining properties and very large soma sizes, ranging from 304 


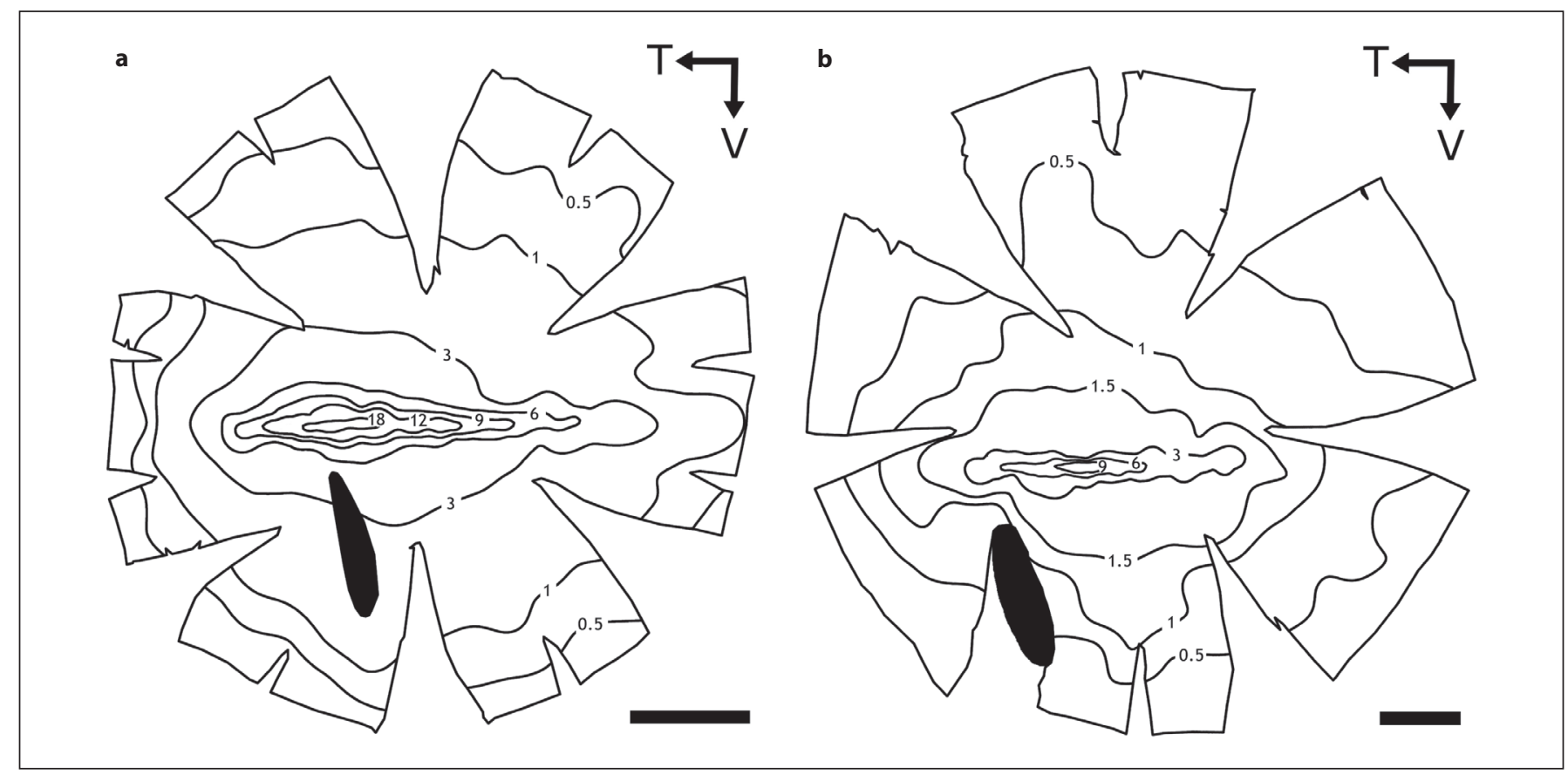

Fig. 2. Topographic maps showing the distribution of ganglion cell densities in retinal wholemounts of the little penguin, E. minor (a), and king penguin, A. patagonicus (b). Numbers on the isodensity lines should be multiplied by $10^{3}$. The oblique strip in the ventral quadrant represents the position of the pecten. $\mathrm{T}=\mathrm{Temporal} ; \mathrm{V}=$ ventral. Scale bars $=5 \mathrm{~mm}$.

to $1,278 \mu \mathrm{m}^{2}(20-40 \mu \mathrm{m}$ in diameter; $\mathrm{n}=212)$ in the little penguin and from 665 to $1,715 \mu \mathrm{m}^{2}(29-47 \mu \mathrm{m}$ in diameter; $\mathrm{n}=175$ ) in the king penguin. They appeared more darkly stained in relation to the other retinal ganglion cells and their soma exhibited a stellate morphology due to the emergence of 5 or 6 primary dendrites (fig. 3a, b, d, f).

In the temporal retina, Nissl-stained giant retinal ganglion cells were distributed in a vertically elongated strip in both penguin species. In the little penguin, this vertical streak of giant ganglion cells is firstly demarcated by isodensity lines of 10 cells $/ \mathrm{mm}^{2}$. Densities gradually increase in an elliptical fashion up to 30 cells $/ \mathrm{mm}^{2}$ and then become more concentrically organized to form an area with an estimated maximum density peak of $72-76$ cells/ $\mathrm{mm}^{2}$ (fig. 3c). Giant ganglion cells in the king penguin also show a vertical organization similar to that seen in the little penguin retinas. However, in the king penguin the topographic organization of giant ganglion cell densities follows a much shallower gradient when compared to the little penguin, ranging from more vertically elongated isodensity lines of 5 cells $/ \mathrm{mm}^{2}$ to a more concentrically organized peak of 39 cells $/ \mathrm{mm}^{2}$ (fig. 3f).

\section{Immunohistochemical Identification of Giant}

Ganglion Cells in the Little Penguin Retina

Immunohistochemistry against MAP2 revealed a conspicuous subpopulation of giant ganglion cells in retinal wholemounts of the little penguin (fig. $4 \mathrm{a}, \mathrm{b}$ ). Giant ganglion cells stained using MAP2 antibody had stellate soma clearly giving rise to either 5 or 6 primary dendrites (fig. 4b, c). These cell profiles exhibited cytological characteristics similar to the giant ganglion cells in Nisslstained preparations, such as general soma morphology and the number of primary dendrites (fig. 4d, e). Another subtype of smaller retinal ganglion cells was faintly labeled by the MAP2 antibody and not included in the quantitative analysis (fig. 4b).

Giant ganglion cells stained by MAP2 antibody appeared more concentrated in the temporal quadrant of the retina but were also clearly identified in the center and other retinal regions. In the temporal retina, giant ganglion cell soma areas ranged from 300 to $1,096 \mu \mathrm{m}^{2}(20$ $37 \mu \mathrm{m}$ in diameter; $\mathrm{n}=205)$; in the center, giant ganglion cell soma areas were smaller, ranging from 208 to $521 \mu \mathrm{m}^{2}$ (16-26 $\mu \mathrm{m}$ in diameter; $\mathrm{n}=59$ ), but exhibited soma morphology very similar to those giant ganglion cells at pe- 

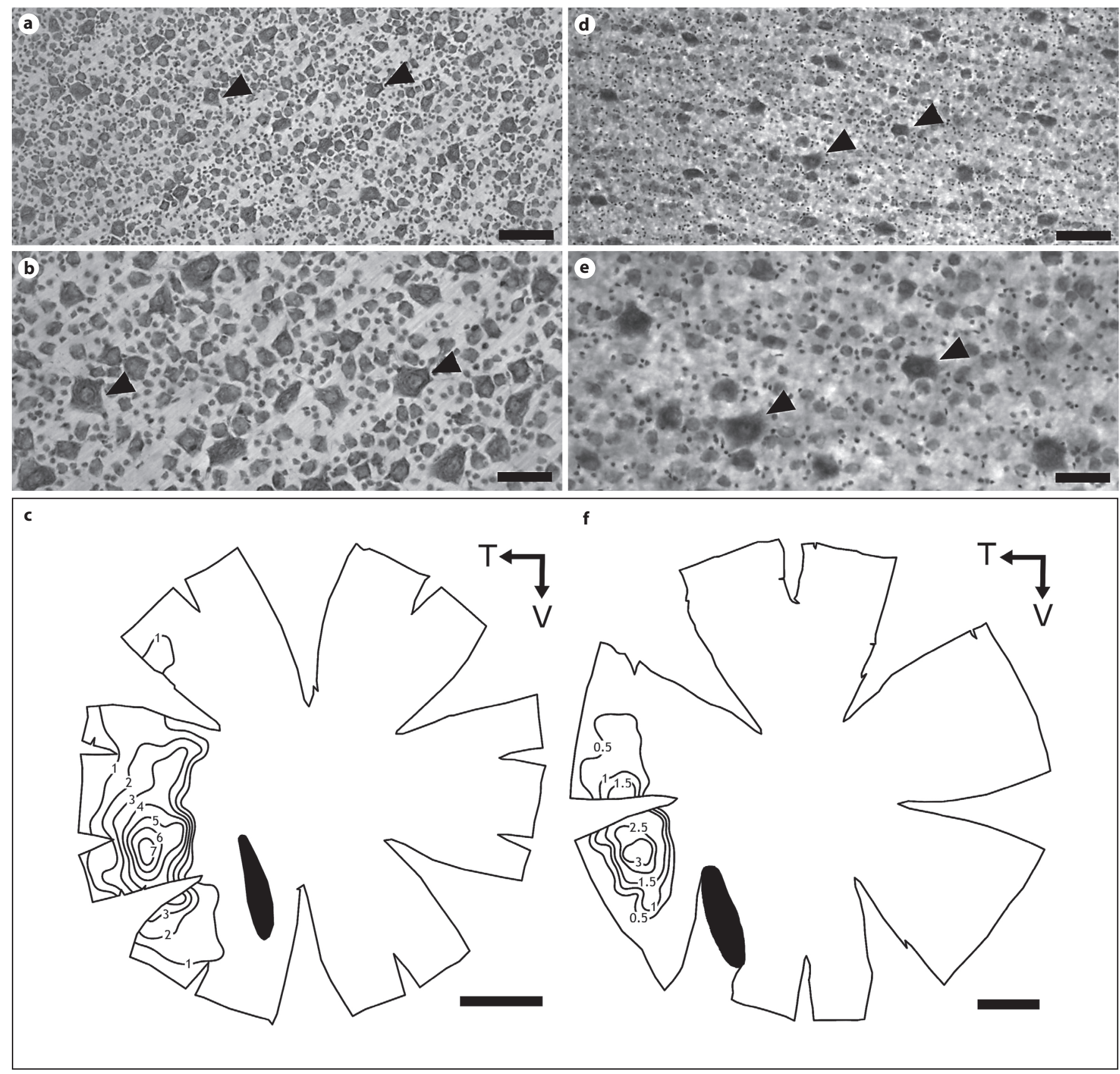

Fig. 3. a, $\mathbf{d}$ Low-power photomicrographs of the region in the temporal retinal quadrant showing the presence of a cohort of giant ganglion cells in Nissl-stained retinal wholemounts of little penguin, E. minor (a), and king penguin, A. patagonicus (d). b, e Higher magnification of the same region illustrating cytological characteristics of giant ganglion cells in the little (b) and king (e) penguins. Examples of giant ganglion cells are indicated by ar- rowheads. Scale bars $=100 \mu \mathrm{m}(\mathbf{a}, \mathbf{d})$ and $50 \mu \mathrm{m}(\mathbf{b}, \mathbf{e}) . \mathbf{c}, \mathbf{f}$ Topographic maps depicting the distribution of giant ganglion cell densities in Nissl-stained retinal wholemounts of little penguin, E. minor (c), and king penguin, A. patagonicus $(\mathbf{f})$. Numbers on the isodensity lines should be multiplied by 10 . The oblique strip in the ventral quadrant represents the position of the pecten. $\mathrm{T}=$ Temporal; $\mathrm{V}=$ ventral. Scale bars $=5 \mathrm{~mm}(\mathbf{c}, \mathbf{f})$. 

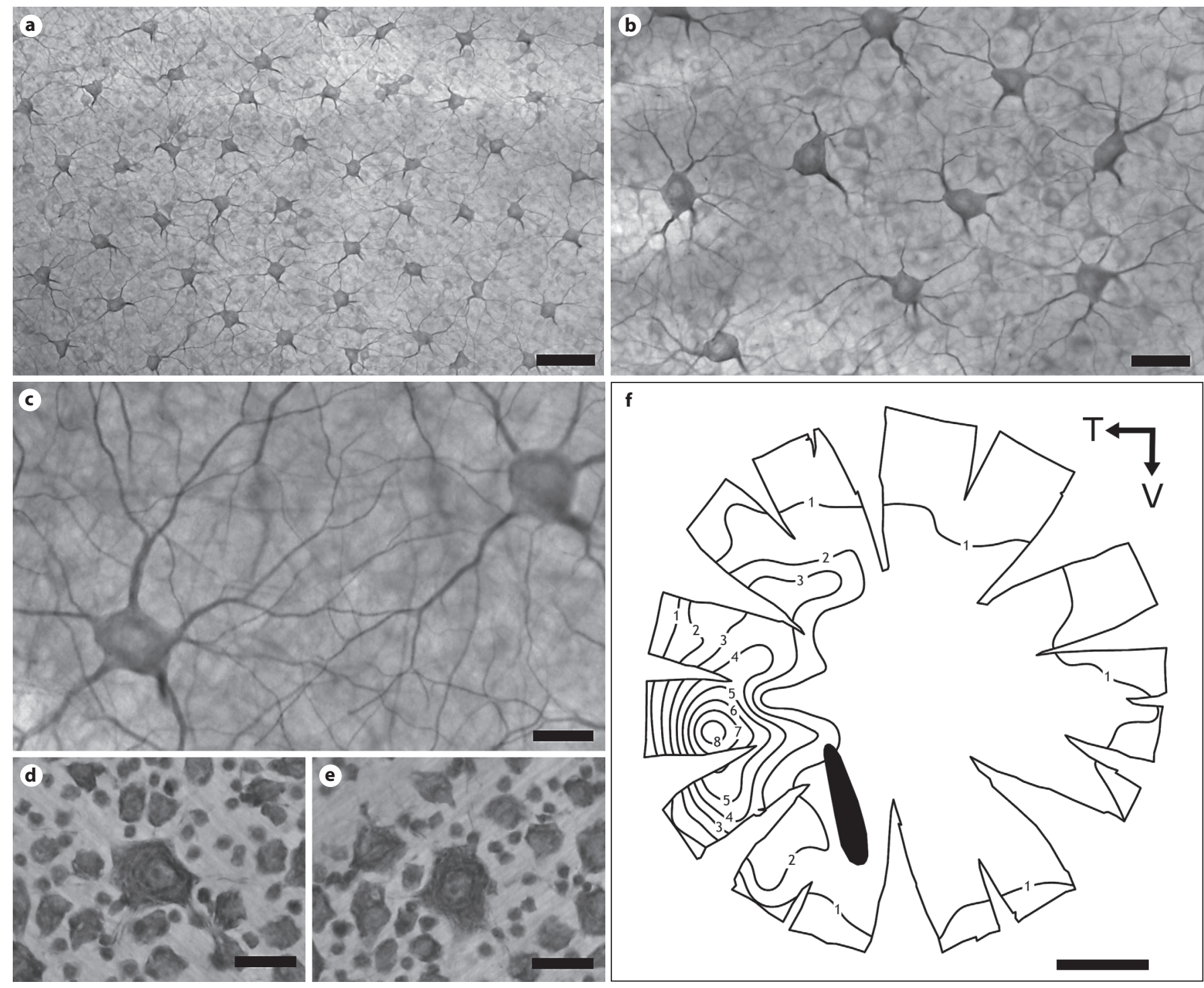

Fig. 4. a-c Photomicrographs of giant ganglion cells immunolabeled with MAP2 in the area gigantocellularis of the little penguin retina at low (a), medium (b) and high (c) magnification. Lightly stained smaller ganglion cell profiles are seen in $\mathbf{b}$. Note the general stellate morphology and number of primary dendrites of the MAP2-positive giant ganglions in $\mathbf{c}$ and compare to the Nisslstained giant ganglion cells with similar morphological characteristics depicted in $\mathbf{d}$ and e. Scale bars $=100 \mu \mathrm{m}(\mathbf{a}), 50 \mu \mathrm{m}(\mathbf{b})$

ripheral locations. A total of 8,704 MAP2-immunopositive giant ganglion cells were estimated using the optical fractionator method in the retinal wholemounts of the little penguin, and they represented $0.7 \%$ of the total population of retinal ganglion cells. The analysis of the distribution of MAP2-immunopositive giant ganglion cells in

and $25 \mu \mathrm{m}$ (c-e). f Topographic map illustrating the total distribution of MAP2-immunopositive giant ganglion cell densities in a little penguin retinal wholemount. Note the similar pattern of organization as shown in the little penguin Nissl-stained ganglion cell density map in figure $3 \mathrm{c}$. Numbers on the isodensity lines should be multiplied by 10 . The oblique strip in the ventral quadrant represents the position of the pecten. $\mathrm{T}=\mathrm{Temporal} ; \mathrm{V}=\mathrm{ven}-$ tral. Scale bar $=5 \mathrm{~mm}$.

reconstructed retinal wholemounts showed a topographic pattern similar to that observed in Nissl-stained wholemounts. Most of the retinal surface in the little penguin is dominated by a flat and homogeneous plateau demarcated by an isodensity line of $10 \mathrm{cells} / \mathrm{mm}^{2}$. In the temporal retina, isodensity lines of 20 and 30 cells $/ \mathrm{mm}^{2}$ reveal a 
Table 3. Optical and anatomical parameters used to estimate the upper limits of spatial resolution of little and king penguin eyes in water and air

\begin{tabular}{lllllll}
\hline Species & $\begin{array}{l}\text { Axial length } \\
\mathrm{mm}\end{array}$ & $\begin{array}{l}\text { Peak of ganglion } \\
\text { cells, cells/mm }\end{array}$ & $\begin{array}{l}\text { PND } \\
\mathrm{mm}\end{array}$ & $\begin{array}{l}\text { RMF } \\
\mathrm{mm} / \text { degree }\end{array}$ & $\begin{array}{l}\text { Spatial resolving power } \\
\text { in water, cycles/degree }\end{array}$ & $\begin{array}{l}\text { Spatial resolving power } \\
\text { in air, cycles/degree }\end{array}$ \\
\hline $\begin{array}{l}\text { E. minor (Emi) } \\
\text { Emi01 (left eye) }\end{array}$ & 17.34 & 21.867 & 12.31 & 0.2148 & 17.07 & 12.81 \\
Emi02 (right eye) & 17.73 & 21.867 & 12.59 & 0.2196 & 17.46 & 13.09 \\
\hline $\begin{array}{l}\text { A.patagonicus (Apa) } \\
\text { Apa01 (right eye) }\end{array}$ & 25.70 & 14.222 & 18.25 & 0.3183 & 20.40 & 15.30 \\
\hline
\end{tabular}

more elongated orientation and define a vertical visual streak as depicted in Nissl-stained retinas. In the inner region of this vertical streak, isodensity lines change from elliptical in shape to more concentrically organized to define a peak giant ganglion cell density of 84 cells $/ \mathrm{mm}^{2}$.

\section{Spatial Resolving Power}

Anatomical estimates of spatial resolving power in the little and king penguins were obtained using the peak density of retinal ganglion cells. In the king penguin, axial length was $25.70 \mathrm{~mm}$ and the PND was $18.25 \mathrm{~mm}$. This resulted in an RMF of $0.3183 \mathrm{~mm} /$ degree. Considering a maximum retinal ganglion cell density of 14,222 cells/ $\mathrm{mm}^{2}$, we estimated spatial Nyquist frequency limits of 20.40 cycles/degree in water. Because a visual image is smaller in air than in water by a factor of 0.75 (ratio of refractive index of air to aqueous or vitreous humor) [Hanke et al., 2009], spatial resolving power in the king penguin was estimated to be 15.30 cycles/degree in air (table 3).

In comparison to the king penguin, the two little penguin specimens examined had smaller eyes, with axial lengths of 17.34 and $17.73 \mathrm{~mm}$, respectively. PNDs were estimated to be 12.31 and $12.59 \mathrm{~mm}$, resulting in RMFs of 0.2148 and $0.2196 \mathrm{~mm} /$ degree, respectively. Using a maximum retinal ganglion cell density of 21,867 cells/ $\mathrm{mm}^{2}$ obtained in both specimens, we estimated a spatial Nyquist frequency of 17.07 cycles/degree and 17.46 cycles/ degree in water and 12.81-13.09 cycles/degree in air (table 3).

\section{Discussion}

In this study, using the retinal wholemount technique and stereological methods, we estimated the total number and topographic distribution of retinal ganglion cells as well as the anatomical spatial resolving power in two penguin species with different evolutionary divergence times and behavioral ecologies: the more basal and pelagic king penguin, $A$. patagonicus, and the more recent and coastal little penguin, E. minor. Our results showed that both species exhibit a very similar linear and elongated arrangement of ganglion cell densities along the nasotemporal meridian characterizing a horizontal visual streak. Anatomical estimates of spatial resolving power were comparable between the species, although they were slightly higher in the king penguin. Mapping of giant ganglion cell distributions using Nissl-stained retinal wholemounts revealed the presence of an area gigantocellularis in the far temporal periphery. In addition, cytological criteria and topographic distribution of giant ganglion cells in the area gigantocellularis were confirmed using immunohistochemistry against MAP2 in little penguin retinal wholemounts.

\section{The Horizontal Visual Streak in Penguins: Influences} of Ecology, Phylogeny or Both?

The topographic analysis of the distribution of retinal ganglion cells revealed the presence of a horizontal visual streak in both king and little penguins, supporting the view that this type of retinal specialization is a common retinal trait in vertebrates that inhabit open and featureless environments [Hughes, 1977]. In functional terms, the horizontal visual streak in both little and king penguins enhances the panoramic view of the horizon and, therefore, would aid in the detection of predators, prey and conspecifics. According to Hughes [1977], more visually complex microhabitats such as vegetated areas exert an adaptive pressure to select more concentric arrangements of cell density affording a more punctual view of objects in the visual field. Surprisingly, the horizontal visual streak in both penguin species revealed a 
very similar pattern showing a prominent linear arrangement of isodensity lines irrespective of the fact that the little penguin is less likely to inhabit open environments than the king penguin during nesting and breeding. Therefore, it seems that the terrestrial microhabitat does not exert a great selective pressure for the adaptive malleability of this retinal pattern in penguins or that there has not been enough evolutionary time to impart a variation in this trait.

Because horizontal visual streaks have been indentified in a multitude of phylogenetically unrelated species, the idea that this trait is essentially selected by environmental pressures to enhance sampling of the visual space along the horizon seems to be very attractive. However, several studies have shown the presence of horizontal visual streaks in species for which the horizon does not represent a relevant feature of their microhabitat, or the absence of this trait in species that inhabit open environments [Freeman and Tancred, 1978; Tancred, 1981; Silveira et al., 1989; Mass and Supin, 1992, 2003; Schiviz et al., 2008]. Stone [1983] suggested that retinal topographic traits can be inherited from a phylogenetic ancestor and do not necessarily represent an adaptive feature to the current lifestyle of a given species. Considering this view, penguins and albatrosses shared a common ancestor that existed approximately 71 million years ago prior to their divergence into separate lineages [Baker et al., 2006], and horizontal visual streaks appear to be a common trait in albatross retinas [Hayes and Brooke, 1990]. This observation would suggest that the prominent horizontal visual streak seen in the little and king penguin retinas might be a plesiomorphic retinal trait inherited from a common seabird ancestor as it is unlikely that it arose multiple times under the same environmental constraints.

\section{The Area Gigantocellularis in Penguins: Ecological} and Evolutionary Constraints

Using Nissl-stained wholemounts, we observed an aggregation of giant retinal ganglion cells in the temporal retina in both little and king penguins, confirming our prediction that these species possessed an area gigantocellularis. The area gigantocellularis was first identified in procellariiform seabirds [Hayes and Brooke, 1990] and subsequently in four species of tyrant flycatcher passerines [Coimbra et al., 2006, 2009]. Suburo et al. [1991] found a similar specialization formed by very large ganglion cells in the retinas of Magellanic penguins. Considering the close phylogenetic relatedness of albatrosses (procellariiform) and penguins [Baker et al., 2006], one can assume that the presence of an area gigantocellularis is a shared trait amongst these seabirds. Further detailed investigations on the phylogenetic distribution of the area gigantocellularis amongst avian taxa is crucial to assess whether this retinal specialization is a homoplastic trait present in seabirds (albatrosses and penguins) and tyrant flycatcher passerines or represents a general retinal trait in birds.

In both little and king penguins, the area gigantocellularis exhibits a vertically elongated organization of the outermost isodensity lines forming a vertical visual streak; within this streak, contours adopted a more elliptical to concentric shape defining a peak in the temporal retina in both species. In terms of visual field sampling, a vertical visual streak is functionally interesting in threedimensional marine environments. Little and king penguins are known to hunt by dive pursuit across different strata within the water column [Reilly and Cullen, 1981; Klomp and Wooller, 1991; Kooyman et al., 1992]; therefore, vertical sampling in the frontal visual field would be advantageous in prey capture. An interesting feature in terms of visual field coverage is that when submerged, penguins experience a reduction of their monocular visual fields and a loss of binocularity, mainly due to the abolishment of the corneal optical power [Martin and Young, 1984; Martin, 1999]. Although binocularity is lost when penguins submerge, visual information can still be extracted from the frontal visual field because monocular visual field margins meet the region of the bill [Martin and Young, 1984; Martin, 1999]. Thus, the presence of an area gigantocellularis in both little and king penguins is in agreement with their ecological needs to extract visual information in their frontal visual field.

A similar topographic arrangement of vertically organized isodensity lines in the temporal quadrant of the retina was shown by Suburo et al. [1991] in the Magellanic penguin, S. magellanicus. Although the two penguin species analyzed in this study and the Magellanic penguin share a very similar topographic organization of giant ganglion cells forming an area gigantocellularis, there are striking differences with regard to the distribution gradients of these cells, as shown previously in generalist and specialist tyrant flycatchers [Coimbra et al., 2006, 2009]. The little penguin exhibits a much steeper gradient in contrast to the shallower gradient observed in the king penguin. The Magellanic penguin has an even steeper gradient, with a peak density of giant ganglion cells of 150 cells $/ \mathrm{mm}^{2}$ [Suburo et al., 1991], which represents roughly double the peak density of $70-84$ cells $/ \mathrm{mm}^{2}$ estimated for the little penguin and approximately 4 times the peak of 39 cells $/ \mathrm{mm}^{2}$ estimated for the king penguin. It appears that even though the peak density of giant ganglion cells 
varies considerably amongst penguin species, there are equivalent estimates of spatial resolution set by these giant ganglion cells. We observed that the maximum density of giant ganglion cells affords a spatial resolving power of approximately 1 cycle/degree in both the little penguin (0.98-1.03 cycles/degree in water, $0.73-0.77$ cycles/degree in air) and king penguin (1.07 cycles/degree in water, 0.80 cycles/degree in air). This suggests that the differences in eye size in the little and king penguins compensate for the differences in peak densities of giant ganglion cells and thereby maintain spatial resolution in the same low range. These low resolution values support the idea that these giant ganglion cells are not involved in fine detail discrimination but rather function in the detection of movement [Hayes et al., 1991].

Using immunohistochemistry against MAP2, we selectively labeled and characterized the spatial distribution of giant ganglion cells in little penguin retinal wholemounts. MAP2 antibodies have been shown to label a subpopulation of large ganglion cells in several vertebrate species [Tucker and Matus, 1987; Gábriel et al., 1992]; however, this is the first investigation to use retinal wholemounts to quantitatively assess the number and distribution of MAP2-immunopositive giant ganglion cells in the avian retina. Our study also corroborates the assumption posed by Hayes et al. [1991] when they first described the organization of the area gigantocellularis using silver staining methods. They argued that due to the capricious nature of silver impregnation staining, it would be likely that the entire population of giant ganglion cells had not been detected in the center and other parts of the procellariiform retinas. Using permeabilization treatments, we were able to identify MAP2-immunopositive giant ganglion cells across the entire retina. In the temporal region, the topography and densities of MAP2-immunopositive giant ganglion cells in the little penguin retina matched the values obtained in estimates using cytological criteria to identify these cells in Nissl-stained preparations. Given the similar quantitative data obtained in MAP2-immunoreacted and Nissl-stained retinal wholemounts, in addition to the conservative nature of this protein across taxa [Viereck et al., 1988], MAP2 is likely to be an excellent marker to selectively label this population of giant ganglion cells in the avian retina.

\section{Anatomical Spatial Resolving Power in Penguins}

Using maximum retinal ganglion cell density and optical parameters to calculate the spatial resolving power in both penguin species, we obtained relatively similar values of resolution for vision underwater and in air. The resolution of 17.07-17.46 cycles/degree in water (12.8113.09 cycles/degree in air) of the little penguin was comparable to a slightly higher underwater resolution of 20.40 cycles/degree (15.30 cycles/degree in air) in the king penguin. Although the peak density of retinal ganglion cells in the little penguin is higher than the values estimated for the king penguin, equivalent estimates of resolution are mainly due to the differences in eye axial length. In the king penguin, lower peak ganglion cell densities combined with a larger eye axial length affords equivalent resolution to the little penguin, which has a higher peak ganglion cell density but a shorter eye axial length. It is likely that, although these birds forage in different strata within the water column and therefore are exposed to differential amounts of light [Reilly and Cullen, 1981; Klomp and Wooller, 1991; Kooyman et al., 1992], differences in peak ganglion cell density and eye size are compensated, giving rise to equivalent resolutions. This might indicate that maximal resolving power would be tuned by aspects of the terrestrial habitats and behaviors of these penguin species, where they would be exposed to relatively similar amounts of light.

Information on anatomical measurements of spatial resolution in birds is scarce. Little and king penguins show lower aerial spatial resolving power when compared to strictly terrestrial birds such as the peacock (Pavo cristatus), with a spatial resolving power of 20.6 cycles/degree [Hart, 2002], and the ostrich (Struthio camelus), with 19.32 cycles/degree [Boire et al., 2001]. This was also the case when we compared the aerial spatial resolving power in the little and king penguin with behavioral estimates of visual acuity of 17.17 cycles/degree in the pigeon (Columba livia) and 30.10 cycles/degree in the American kestrel (Falco sparverius) [Ghim and Hodos, 2006]. Although anatomical estimates of spatial resolving power are usually higher than behavioral estimates of visual acuity, correspondence between anatomical ( 8.40 cycles/ degree) and behavioral (6.98 cycles/degree) measurements has been observed for the barn owl (Tyto alba) [Wathey and Pettigrew, 1989; Ghim and Hodos, 2006]; this suggests that anatomical and behavioral methods may be comparable in many avian species. Using this approach, little and king penguin aerial spatial resolving power is higher when compared to barn owls and other terrestrial bird species (2.29-7.56 cycles/degree). Likewise, both aerial and underwater spatial resolving power in the little and king penguin is higher when compared to anatomical estimates in pinnipeds such as seals (8.511.5 cycles/degree in water, 6.5-8.7 cycles/degree in air) and sea lions (7.2 cycles/degree in water, 5.3 cycles/degree 
in air) that share similar environments and utilize equivalent food resources [Mass and Supin, 1992, 2003, 2005; Hanke et al., 2009; Mass and Supin, 2010]. Therefore, when compared with sympatric marine mammals and some terrestrial birds, the higher spatial resolving power in the little and king penguin would afford these seabirds enhanced fine detail discrimination in a plethora of ecological tasks, including prey detection, predator avoidance and mate recognition both in air and water.

\section{Acknowledgements}

We would like to express our gratitude to the veterinary staff at Perth Zoo, Western Australia, especially to Dr. Simone Vitali, Caroline Lawrence, Cathy Cooper and Mikaylie Wilson for pro- viding the little penguin eyes. We also thank Caroline Kerr for invaluable assistance at different stages of the project. We are indebted to Prof. Cristovam Diniz for the enlightening discussions about stereological methods; Prof. Elizabeth Yamada for valuable instructions on the use of collagenase; the geographer Luis Barbosa for the immeasurable advice on the use of Arcview software to construct the topographic maps, and Prof. Howard Howland for advice on the optics of penguin eyes in air and water. This study was funded in part by an Australian Research Council Discovery Project and Queen Elizabeth II Fellowship (DP0558681). Funding from the United States National Science Foundation (to P.M.N., grant OPP 0128913) and logistical and funding support were provided by the Institut Polaire Paul Emile Victor. J.P.C. was supported by Endeavour International Postgraduate Research (IPRS) and the University of Queensland Research (UQRS) scholarships at the University of Queensland and Scholarship for International Research Fees (SIRF) and Univeristy International Stipend (UIS) at the University of Western Australia.

\section{References}

Amrein I, Slomianka L (2010): A morphologically distinct granule cell type in the dentate gyrus of the red fox correlates with adult hippocampal neurogenesis. Brain Res 1328:1224.

- Baker AJ, Pereira SL, Haddrath OP, Edge KA (2006): Multiple gene evidence for expansion of extant penguins out of Antarctica due to global cooling. Proc R Soc Lond B Biol Sci 273:11-17.

- Bhagwandin A, Gravett N, Hemingway J, Oosthuizen MK, Bennett NC, Siegel JM, Manger PR (2011): Orexinergic neuron numbers in three species of African mole rats with rhythmic and arrhythmic chronotypes. Neuroscience 199:153-165.

-Boire D, Dufour JS, Theoret H, Ptito M (2001): Quantitative analysis of the retinal ganglion cell layer in the ostrich, Struthio camelus. Brain Behav Evol 58:343-355.

Bowmaker JK, Martin GR (1985): Visual pigments and oil droplets in the penguin, Spheniscus humboldti. J Comp Physiol A Sens Neural Behav Physiol 156:71-77.

Bravo H, Pettigrew JD (1981): The distribution of neurons projecting from the retina and visual cortex to the thalamus and optic tectum of the barn owl, Tyto alba, and the burrowing owl, Speotyto cunicularia. J Comp Neurol 199:419-441.

Cannell BL, Cullen JM (1998): The foraging behaviour of Little Penguins Eudyptula minor at different light levels. Ibis 140:467-471.

-Coimbra JP, Marceliano MLV, Andrade-da-Costa BLS, Yamada ES (2006): The retina of tyrant flycatchers: topographic organization of neuronal density and size in the ganglion cell layer of the great kiskadee Pitangus sulphuratus and the rusty margined flycatcher Myiozetetes cayanensis (Aves: Tyrannidae). Brain Behav Evol 68:15-25.
Coimbra JP, Trévia N, Marceliano MLV, Andrade-da-Costa BLS, Picanço-Diniz CW, Yamada ES (2009): Number and distribution of neurons in the retinal ganglion cell layer in relation to foraging behaviors of tyrant flycatchers. J Comp Neurol 514:66-73.

Collin SP (1999): Behavioural ecology and retinal cell topography; in Archer SN, Djamgoz BMS, Loew ER, Partridge JC, Vellarga S (eds): Adaptive Mechanisms in the Ecology of Vision. Dordrecht, Kluwer, pp 509-535.

Ehrlich D (1981): Regional specialization of the chick retina as revealed by the size and density of neurons in the ganglion cell layer. J Comp Neurol 195:643-657.

Freeman B, Tancred E (1978): Number and distribution of ganglion cells in the retina of the brush-tailed possum, Trichosurus vulpecula. J Comp Neurol 177:557-567.

Gábriel R, Wilhelm M, Straznicky C (1992): Microtubule-associated protein 2 (MAP2)-immunoreactive neurons in the retina of Bufo marinus: colocalisation with tyrosine hydroxylase and serotonin in amacrine cells. Cell Tissue Res 269:175-182.

Gales R, Williams C, Ritz D (1990): Foraging behaviour of the little penguin, Eudyptula minor: initial results and assessment of instrument effect. J Zool 220:61-85.

-Gatome CW, Slomianka L, Lipp HP, Amrein I (2010a): Number estimates of neuronal phenotypes in layer II of the medial entorhinal cortex of rat and mouse. Neuroscience 170: 156-165.

-Gatome CW, Slomianka L, Mwangi DK, Lipp HP, Amrein I (2010b): The entorhinal cortex of the Megachiroptera: a comparative study of Wahlberg's epauletted fruit bat and the straw-coloured fruit bat. Brain Struct Funct 214:375-393.
Ghim MM, Hodos W (2006): Spatial contrast sensitivity of birds. J Comp Physiol A 192: 523-534.

Glaser EM, Wilson PD (1998): The coefficient of error of optical fractionator population size estimates: a computer simulation comparing three estimators. J Microsc 192:163171.

Gomes FL, Silveira LCL, Saito CA, Yamada ES (2005): Density, proportion, and dendritic coverage of retinal ganglion cells of the common marmoset (Callithrix jacchus jacchus). Braz J Med Biol Res 38:915-924.

Gundersen HJG (1977): Notes on the estimation of the numerical density of arbitrary profiles: the edge effect. J Microsc 111:219223.

Hackett SJ, Kimball RT, Reddy S, Bowie RCK, Braun EL, Braun MJ, Chojnowski JL, Cox WA, Han KL, Harshman J, Huddleston CJ, Marks BD, Miglia KJ, Moore WS, Sheldon FH, Steadman DW, Witt CC, Yuri T (2008): A phylogenomic study of birds reveals their evolutionary history. Science 320:17631768.

Hanke FD, Peichl L, Dehnhardt G (2009): Retinal ganglion cell topography in juvenile harbor seals (Phoca vitulina). Brain Behav Evol 74:102-109.

-Hart NS (2002): Vision in the peafowl (Aves: Pavo cristatus). J Exp Biol 205:3925-3935.

Hart NS, Coimbra JP, Collin SP, Westhoff G (2012): Photoreceptor types, visual pigments, and topographic specializations in the retinas of hydrophiid sea snakes. J Comp Neurol 520:1246-1261.

Hayes B, Martin GR, Brooke ML (1991): Novel area serving binocular vision in the retinae of procellariiform seabirds. Brain Behav Evol 37:79-84. 
-Hayes BP, Brooke ML (1990): Retinal ganglion cell distribution and behaviour in procellariiform seabirds. Vision Res 30:1277-1289.

Hemmi JM, Grunert U (1999): Distribution of photoreceptor types in the retina of a marsupial, the tammar wallaby (Macropus eugenii). Vis Neurosci 16:291-302.

Howland HC, Sivak JG (1984): Penguin vision in air and water. Vision Res 24:1905-1909.

Hughes A (1977): The Topography of Vision in Mammals of Contrasting Life Style: Comparative Optics and Retinal Organisation. Handbook of Sensory Physiology vol 7. Crescitelli F (ed): The Visual System of Vertebrates. Berlin, Springer, pp 697-756.

- Kern A, Siebert U, Cozzi B, Hof PR, Oelschlager HHA (2011): Stereology of the neocortex in Odontocetes: qualitative, quantitative, and functional Implications. Brain Behav Evol 77:79-90.

Klomp NI, Wooller RD (1988): Diet of little penguins, Eudyptula minor, from Penguin Island, western Australia. Marine Freshwater Res 39:633-639.

-Kooyman GL, Cherel Y, Le Maho Y, Croxall JP, Thorson PH, Ridoux V, Kooyman CA (1992): Diving behavior and energetics during foraging cycles in king penguins. Ecol Monogr 143-163.

Ksepka DT, Ando T (2011): Penguins past, present, and future: trends in the evolution of the Sphenisciformes; in Dyke G, Kaiser D (eds): Living Dinosaurs: The Evolutionary History of Modern Birds. Oxford, Wiley, pp 155-186.

Livezey BC, Zusi RL (2007): Higher-order phylogeny of modern birds (Theropoda, Aves: Neornithes): based on comparative anatomy. II. Analysis and discussion. Zool J Linn Soc 149:1-95.

Martin GR (1999): Eye structure and foraging in King Penguins Aptenodytes patagonicus. Ibis 141:444-450.

-Martin GR, Young SR (1984): The eye of the Humboldt Penguin, Spheniscus humboldti: visual fields and schematic optics. Proc R Soc Lond B Biol Sci 223:197-222.

Martínez I (1992): Family Spheniscidae (penguins); in del Hoyo J, Elliott A, Sargatal J (eds): Handbook of the Birds of the World. Barcelona, Lynx Edicions, vol 1, pp 140-172.

-Mass AM, Supin AY (1992): Peak density, size and regional distribution of ganglion cells in the retina of the Fur Seal Callorhinus ursinus. Brain Behav Evol 39:69-76.

Mass AM, Supin AY (2003): Retinal topography of the harp seal Pagophilus groenlandicus. Brain Behav Evol 62:212-222.

Mass AM, Supin AY (2005): Ganglion cell topography and retinal resolution of the Steller sea lion (Eumetopias jubatus). Aquat Mamm 31: 393-402.

Mass AM, Supin AY (2010): Retinal ganglion cell layer of the caspian seal Pusa caspica: topography and localization of the high-resolution area. Brain Behav Evol 76:144-153.
Peichl L (1991): Alpha ganglion cells in mammalian retinae: common properties, species differences, and some comments on other ganglion cells. Vis Neurosci 7:155-169.

Peichl L (1992): Topography of ganglion cells in the dog and wolf retina. J Comp Neurol 324: 603-620.

Peichl L, Němec P, Burda H (2004): Unusual cone and rod properties in subterranean African mole-rats (Rodentia, Bathyergidae). Eur J Neurosci 19:1545-1558.

Peichl L, Ott H, Boycott BB (1987): Alpha ganglion cells in mammalian retinae. Proc R Soc Lond B Biol Sci 169-197.

Petry HM, Erichsen JT, Szél Á (1993): Immunocytochemical identification of photoreceptor populations in the tree shrew retina. Brain Res 616:344-350.

- Pettigrew JD, Dreher B, Hopkins CS, McCall MJ, Brown M (1988): Peak density and distribution of ganglion cells in the retinae of microchiropteran bats: implications for visual acuity. Brain Behav Evol 32:39-56.

Reilly PN, Cullen JM (1981): The little penguin Eudyptula minor in Victoria. II. Breeding. Emu 81:1-19.

Reuter T, Peichl L (2008): Structure and function of the retina in aquatic tetrapods; in Thewissen JGM, Nummela S (eds): Sensory Evolution on the Threshold - Adaptations in Secondarily Aquatic Vertebrates. Berkeley, University of California Press, pp 149172.

Ropert-Coudert Y, Kato A, Wilson RP, Cannell B (2006): Foraging strategies and prey encounter rate of free-ranging Little Penguins. Mar Biol 149:139-148.

-Saper CB, Sawchenko PE (2003): Magic peptides, magic antibodies: guidelines for appropriate controls for immunohistochemistry. J Comp Neurol 465:161-163.

-Schiviz AN, RufT, Kuebber-Heiss A, Schubert C, Ahnelt PK (2008): Retinal cone topography of artiodactyl mammals: influence of body height and habitat. J Comp Neurol 507:13361350.

Schmitz C, Hof PR (2005): Design-based stereology in neuroscience. Neuroscience 130:813831.

-Silveira LCL, Picanço-Diniz CW, Oswaldo-Cruz E (1989): Distribution and size of ganglion cells in the retinae of large Amazon rodents. Vis Neurosci 2:221-235.

-Sivak J, Howland HC, McGill-Harelstad P (1987): Vision of the Humboldt penguin (Spheniscus humboldti) in air and water. Proc R Soc Lond B Biol Sci 229:467-472.

-Sivak JG (1976): The role of a flat cornea in the amphibious behaviour of the blackfoot penguin (Spheniscus demersus). Can J Zool 54: 1341-1345.

Sivak JG, Millodot M (1977): Optical performance of the penguin eye in air and water. J Comp Physiol A Sens Neural Behav Physiol 119:241-247.
Slomianka L, West MJ (2005): Estimators of the precision of stereological estimates: an example based on the CA1 pyramidal cell layer of rats. Neuroscience 136:757-767.

Snyder AW, Miller WH (1977): Photoreceptor diameter and spacing for highest resolving power. J Opt Soc Am 67:696-698.

Sterio DC (1984): The unbiased estimation of number and sizes of arbitrary particles using the disector. J Microsc 134:127-136.

Stone J (1981): The Whole Mount Handbook: A Guide to the Preparation and Analysis of Retinal Whole Mounts. Sydney, Maitland Publications.

Stone J (1983): Parallel Processing in the Visual System. New York, Plenum.

Suburo AM, Herrero MV, Scolaro JA (1991): Regionalization of the ganglion cell layer in the retina of the Magellanic penguin (Spheniscus magellanicus). Colonial Waterbirds 14:1724.

- Suburo AM, Scolaro JA (1999): Environmental adaptations in the retina of the Magellanic penguin: photoreceptors and outer plexiform layer. Waterbirds 22:111-119.

Tancred E (1981): The distribution and sizes of ganglion cells in the retinas of five Australian marsupials. J Comp Neurol 196:585603.

Tucker RP, Matus AI (1987): Developmental regulation of two microtubule-associated proteins (MAP2 and MAP5) in the embryonic avian retina. Development 101:535-546.

-Viereck C, Tucker RP, Binder LI, Matus A (1988) Phylogenetic conservation of brain microtubule-associated proteins MAP2 and tau. Neuroscience 26:893-904.

-Wässle H (2004): Parallel processing in the mammalian retina. Nat Rev Neurosci 5:747757.

Wässle H, Peichl L, Boycott BB (1981): Morphology and topography of on- and off-alpha cells in the cat retina. Proc R Soc Lond B Biol Sci 212:157-175.

Watanabe M, Rodieck RW (1989): Parasol and midget ganglion cells of the primate retina. J Comp Neurol 289:434-454.

-Wathey JC, Pettigrew JD (1989): Quantitative analysis of the retinal ganglion cell layer and optic nerve of the barn owl Tyto alba. Brain Behav Evol 33:279-292.

-West MJ, Slomianka L, Gundersen HJG (1991): Unbiased stereological estimation of the total number of neurons in the subdivisions of the rat hippocampus using the optical fractionator. Anat Rec 231:482-497.

Williams DR, Coletta NJ (1987): Cone spacing and the visual resolution limit. J Opt Soc Am A 4:1514-1523.

Wood CA (1917): The Fundus Oculi of Birds: Especially as Viewed by the Ophthalmoscope; A Study in the Comparative Anatomy and Physiology. Chicago, Lakeside.

- Yamada ES, Silveira LCL, Perry VH, Franco ECS (2001): M and P retinal ganglion cells of the owl monkey: morphology, size and photoreceptor convergence. Vision Res 41:119-131. 
